Meryem Yalcin

\title{
Progressive Development of Creative Design Skills from Kindergarden Education
}

\begin{abstract}
This article offers an alternative view of design education, emphasising on its introduction in kindergarten and proposing a curriculum that covers design issues for introduction in kindergarten. This approach is suited to developing creative thinking skills. In an environment where children imagine, create, practice, modify, recognise, manipulate and share knowledge, experiences and objects are crucial in design education. Early childhood education should be advanced based on basic design issues-such as design principles, conceptualization, 2D/3D spatial allocation and composition-more comprehensively, which will enable children to construct perceptual, critical and analytic view points at an early age and develop these perspectives in the future. Based on this argument, the study model for design education in kindergarten, which will instil in children strong design knowledge, as well as stimulate their cognitive development.
\end{abstract}

Keywords: children-design relations, basic design, develop creative thinking

\section{Introduction}

Until the mid-1960s, children's drawings were one of the most popular themes in professional writing on creative education. Then, the topic virtually disappeared, not returning until the 1990s. The focus of curricula, teacher training and research shifted to picture analysis, popular forms of visual communication, and cultural studies (Ackermann, 2004; Lindström, 2006). One of the most important areas of child and educational psychology is the issue of creativity in children, the development of this creativity, and its significance to the general development and maturation of the child. It is important to enable and direct children correctly during the time period when they develop and learn quickly and construct their knowledge immediately (Florida, 2002; Vygotsky, 2004). All participants in this 'creative learning community' share principles and values based on the idea of children being competent and creative learners, which is articulated so well by the approach in design disciplines (Fawcett \& Hay, 2004). The domain of child and youth study related to the visual arts includes much more than the study of children's drawings (Brosterman, 1997; Fulghum, 1986; Hirsh, Golinkoff \& Eyer, 2003; Leinonen \&Venninen, 2012; Sawyer, 2006). Moreover, at an age when they are very creative, they imagine, create, practice, modify, discover, recognise, manipulate and share, which is effective in design education but is not included professionally in the early childhood curriculum for design issues.

In agreement with this, it is known that advanced creative thinking skills are best achieved when children are encouraged during early childhood education. Artistic development occurs between 2 and 6 years of age more than at any other time during a child's development. During this four-year period, children progress from scribbles to representation, and from disorganised to organised representations. Drawings and modelling produced by children during these years are filled with a vitality and freshness that diminishes rapidly as they grow older (Lindström, 2011; Resnick, 1998; Rosario \& Collazo, 1981; Thompson, 1995, 2007).

On the other hand, preschools are undergoing a dramatic change. For nearly 200 years since the first kindergarten opened in 1837, kindergarten has been a time for telling stories, building castles, drawing pictures and learning to share. However, this situation is starting to change. In essence, Froebel was designing for designers when he designed objects that ena- 
bled children in his kindergarten to create their own designs. Froebel's work can be viewed as an early example of Seymour Papert's constructionist approach to education, which aims to engage learners in design experiences that have personal meaning. Froebel was limited by the materials available in the early $19^{\text {th }}$ century when creating his Gifts. With today's advanced electronic and digital technologies, we can create new types of construction kits, expanding Froebel's kindergarten approach to older students working on more advanced projects and learning more developed ideas. With Mindstorms and Crickets, for example, children can create dynamic, interactive constructions, and in the process, learn concepts related to sensing, feedback and control (Dudek, 1996, 2000).

Creativity is at the root of a perceptual, critical and analytic point of view at a very early age to be developed in the future. Friedrich Froebel understood this idea when he opened the world's first kindergarten in 1837. Froebel filled his kindergarten with physical objects (such as blocks, beads and tiles) that children could use for building, designing and creating. These objects became known as Froebel's Gifts (Resnick, 1998). He found that interaction with the three-dimensional world was essential for meaning making. Through embodied interactions with the environment, people get know about its manifold properties, as well as about their own bodies and minds (Fredriksen, 2011). Moreover, providing knowledge, experiences and objects through play are crucial for design education. However, these issues must be professsionally processed and integrated more comprehensively in a curriculum with design principles, conceptualisation, 2D/3D spatial allocation, colour, texture and light composition.

\section{Method and Research}

The basis for this hypothetical study is the construction of practices of design education in preschool and continuing them in the future based on the empirical knowledge of its absence (Black, 2001; Oxman, 1999, 2001). With this as the argument, this review study (Torracco, 2005) aims to establish the foundation of child creativity on three main concerns: design education should be started in preschool education; this education has to be continuous and be handled pedagogically and professionally by design discipline; and a clear curriculum needs to be established (Ackermann, 2004; Fawcett \& Hay, 2004; Fulghum, 1986; Rosario \& Collazo, 1981; Sawyer, 2006). In addition, some findings from a questionare survey on interior architecture students from the Fine Arts, Design and Architecture Faculty, TOBB Economy and Technology, Ankara, Turkey, are also presented and discussed in light of the findings from this literature review. With these aims in mind, the background for the present research and the basis for this research argument are presented under the following headings: Creative Design Skills in the Preschool Curriculum: Educator-Designer Collaboration, Preschool Curriculum and Basic Design Education, and Creative Thinking Cycle in Preschool Education: A Proposal for a "Preschool Design Education Model." A review of the relevant literature indicated that a design education curriculum for preschools is either absent or, if present, is inadequate. Therefore, research on this topic was analysed (Maxwell \& Cole, 1995; Niederhauser, Wetzel \& Lindstrom, 2004; Torracco, 2005) and used to establish a preschool design education model, which has been proposed in this study. Finally, this model has been described and evaluated.

\section{Creative design skills in the preschool curriculum: educator-designer collaboration}

In recent studies, several factors related to artistic creativity were monitored in preschool children, such as sensitivity to problems, elaboration, flexibility, fluency, originality and redefinition. Teachers rarely give children the chance to present and apply their ideas. The themes that are offered frequently require children to simply make a representation of something that already exists rather than provide an incentive for children to think about what 
different creations could look like. The foregoing approach has serious limitations. Children have no chance to express their own experiences, create unique forms, or improve their ability for observation. Creations that result from a lesson designed in this way often strongly resemble each other. In order for children to attain the goals of the curriculum, they should be gradually introduced to some features of the process of creative education (Batič, 2014). According to Ellis and Morrison (1998), the use of various materials allows children to explore freely, to test their ideas, and to solve design problems in a creative way, while at the same time provide flexibility for their personal expression and creativity. Indeed, Tomšic `Cerkez (2004) strongly recommends that teachers provide children with all the materials with which they are capable of working.

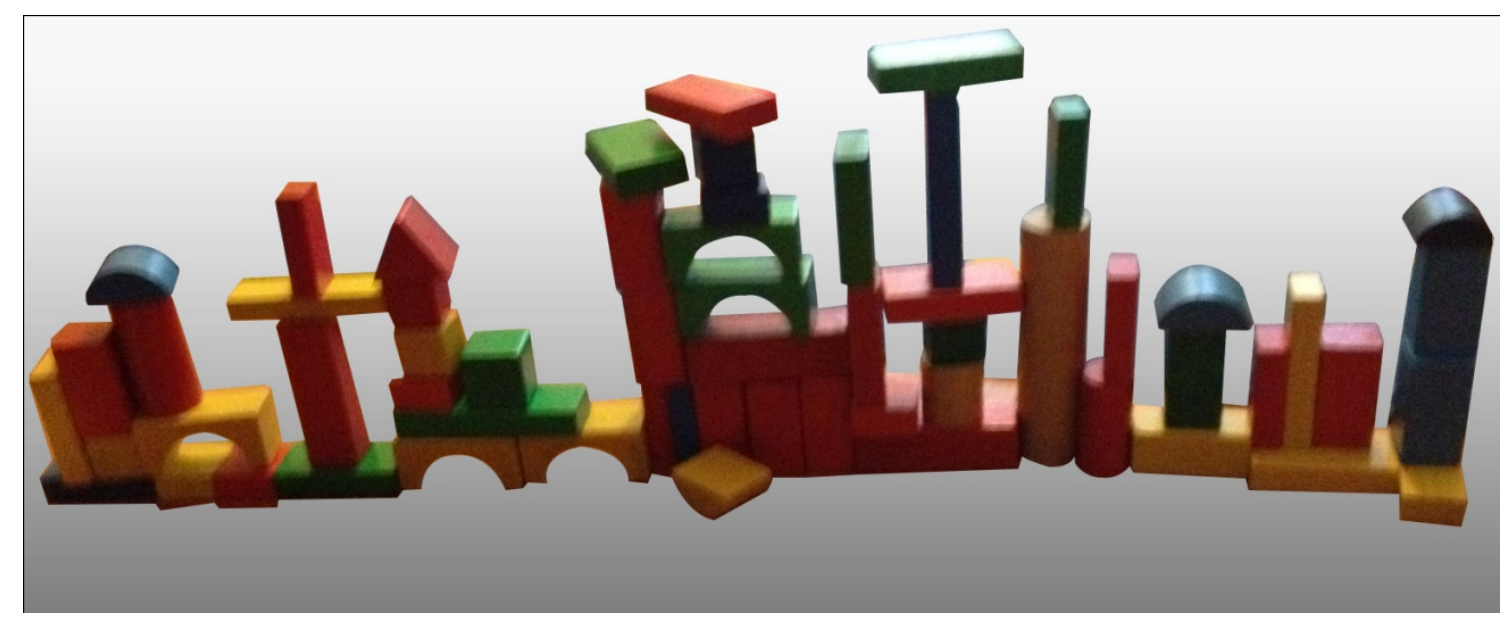

Figure 1. A four year old childs' 'structure design' made of blocks which represents structures built juxtaposition.

A multidimensional assessment gives students feedback, which helps them discover their strengths and identify areas of improvement. On the basis of these observations, Lindström (2006) proposed a four-step approach for schools to help children in creative education: investigative work, inventiveness, ability to use models, and capacity for self-assessment.

Educators can facilitate and support a child's depth of creative learning

- to develop reflective, creative early years;

- to work locally, and encourage regionally with regard to creations;

- to establish effective models and samples; and

- to document, evaluate and disseminate this progress and actively contribute to a growing body of practice.

Children should have the opportunity to gain meaningful creative experience through motion and through interaction with the real world or, when the latter is not possible, by means of modern teaching media. It is also important that preschools enable teachers to provide children with a suitable variety of creative materials that can facilitate the creation of a solution, as well as demonstrate how materials should be properly handled. The motif should be based on their own experience of the creations that they can elaborate in their imagination (Batič, 2014; Härkönen, 2002).

The information available about the current practices indicates that it does not foster children's creativity as effectively as possible. For instance, instead of making replicas of existing creations, the children may be given tasks based on familiar (real-world) tools, which 
nevertheless enable them to experience them on their own, identify a problem, find original solutions and experiment with creative materials, as prescribed by the curriculum (Ackermann, 2004).

The experience allowed for collegiality and the varied contributions of designers, such as openness, quality of questioning, and different ways of responding to children, as might be expected. In addition, designers provide information about all kinds of interesting, aesthetically pleasing materials and their potential; how to make things; and other exciting new possibilities. The educators whereas add the drama and movement contributions with their own special perspectives and ways of thinking (Emilson \& Johansson, 2009; Fawcett \& Hay, 2004).

Circumstantial combination of two applied disciplines - pedagogy and design - can contribute to the improvement of the quality of basic design education with regard to designing objects; acquiring a sense of $2 \mathrm{D} / 3 \mathrm{D}$ space allocation; and stimulating children to provoke questions, suggest answers, inspire action, and think of acquiring new skills. The challenge for design education in older students is developing an understanding of the buildup of creative skills in early childhood education and complementary construction in the future. In addition, children have a special way of looking at spaces and objects. Often, the tools with which children interact become objects with their own visual identity, different for each child, in which the tactile capabilities of children are also enhanced through education. Consequently, it is a controversial and complicated issue. Design knowledge during early childhood education has been examined in detail below.

\section{Preschool curriculum and basic design education}

Educational media for pre-school entities directly or indirectly affect systematic learning and formation of specific objectives. Consequently, children should be presented with these opportunities by allocating them in flexible and well-processed programs for providing unlimited freedom where they can experience themselves and develop skills. It is essential to direct children's unlimited imagination, creativity and curiosity corresponding to child development and to allow them to integrate broad-spanning opportunities. During this process, kindergarten students develop and refine their abilities as creative thinkers. They learn to develop their own ideas, try them out, test the boundaries, experiment with alternatives, get input from others, and-perhaps most significantly-generate new ideas based on their experiences. In reality, the steps in the process are not distinct or sequential. Imagining, creating, playing, sharing, and reflecting are mixed together in many different ways (Bryant \& Hungerford, 1977; Fulghum, 1986; Göncu, Main \& Abel, 2009; Thompson, 1995). However, the key elements are always present, in one form or another. Some of the most creative artists and inventors of the $20^{\text {th }}$ century credit their kindergarten experiences with laying the foundation (Schön, 1987; Thompson, 1995) for their later success. They described their kindergarten experience in which children imagine what they want to do, create projects based on their ideas, play with their creations, share their ideas and creations with others, and reflect on their experiences - all of which lead them to imagine about new ideas and projects. The visual art curriculum for early childhood education is quite noncommittal. It emphasizes the necessity of experiencing art activities, self-expression, fun and satisfaction, and an opportunity for children to present their own points of view. It focuses on children depicting objects and events idiosyncratically, by using different media and techniques, and observing and describing their product. In an age in which art and scientific curiosity are not a prominent part of the education system and are deemed less important than acquiring competencies aimed at technological development, it is crucial to provide clear answers and solutions for developing children's creativity (Resnick, 1998). 
For instance, a survey was conducted among the interior architecture students at the Department of Interior Arcitecture and Environmental Design, TOBB University of Economics and Technology, Ankara, Turkey. The respondents were randomly selected from among sophomore-, junior- and senior-level students. Out of the 110 students who participated in the research, $87.5 \%$ had attended in kindergarten. The study augmented the idea that design education should begin in kindergarten and continue progressively, without interruption. Over half of the students stated that they have had none or inconsiderable design education since kindergarten; $31.3 \%$ stated that their design education after kindergarten had progressed; and only $7.5 \%$ of the students stated that their art, design and creativity education had been continued after kindergarten. It can be understood from the answers that the students who responded did not feel that they developed their creativity potentially during their art and design education after kindergarten. In this period, when the basic design knowledge from preschool education is supposed to be developed, it may be beneficial to address both design issues and corresponding pedagogical aspects.

As mentioned earlier, children younger than 6 years of age show many examples of aesthetic pleasure and creative approaches within the preschool educational activities. Accordingly, educators of young children provide material, motivation, structure and the psychological environment for the visual art education of their students. Interactions between preschool children and their educators have been studied by Rosario and Collazo (1981) and Thompson (1995), who found that the quality of art experiences of preschool or kindergarten children is particularly vulnerable to the expertise of the educators. However, younger children generally are unable to seek information from libraries or effectively discuss subject matters with peers, educators and parents. Therefore, they depend on educators to decide their creative activities and for feedback on their performance. In other words, children in preschool and/or kindergarten are totally dependent on educators to provide design materials and activities in the school setting.

\section{Creative thinking cycle in preschool education: A proposal for a "preschool design education model"}

Recently, design educators have started to explore the learning style characteristics of students that can be used for the enhancement of learning in design (Demirbas \& Demirkan, 2003, 2007; Kvan \&Yunyan, 2005; Uluoğlu, 2000). The literature suggests that design students should learn by experiencing, reflecting, thinking and acting in the process of finding solutions to the assigned design problems. Therefore, design education can be considered as being in accordance with Kolb's (1984) experiential learning theory (ELT). This study focuses on learning in design education by using Kolb's learning styles and explores the relationship between learning styles, gender and academic performance. The learning styles according to Kolb's ELT are described as the individual's intellectual approach to the processing of information (Chou \& Wang, 2000; Kolb \& Kolb, 2005). Consequently, each child has a preferred way of perceiving, organising and retaining that is distinctive and consistent.

On the contrary, iteration is at the heart of the creative process. As mentioned previously, the process of "imagine, create, play, share and reflect" inevitably leads to new ideas, which leads back to imagine and the beginning of a new cycle, within the process of constantly critiquing, adjusting, modifying and revising. This is imperative for becoming a creative thinker. Historically, kindergarten has provided a good foundation for creative thinking where the first creative thinking cycle takes place. Unfortunately, after leaving kindergarten, children usually do not have the opportunity to iterate on what they learned in kindergarten and to continue to develop as creative thinkers (Resnick, 1998). Extending the kindergarten approach and providing opportunities for learners of all ages to build on their experiences enables them to refine their abilities as creative thinkers by iteration throughout their future 
academic life. The practices of design learning during early childhood education should be developed to facilitate the design process for what can be considered a crucial activity where educators and children share experiences. Participation also includes the participatory skills of negotiation and sharing (Göncu et al., 2009; Thomson, 2007), which according to educator descriptions, can help obtain results in common decision-making and shared planning together with educators and children. When design learning involves planning of educational practices beforehand (Härkönen, 2002), it could also involve planning of design learning practices. A child's age impacts the participatory practices available to them (Resnick, 1998).

In this context, the process of planning activities is an important process in design education. Educators and children should mutually participate in the creative thinking cycle. Enabling children to apply basic design principles, attitudes and manipulation of materials is essential for classroom activities at the kindergarten level, in which emphasis is placed on the developmental stages of design and how they are affected by the intellectual, physical, perceptual, aesthetic, creative, emotional and social growth of children (Berthelsen, Brownlee \& Johansson, 2009; Brosterman, 1997). The design education of preschool children covers rather extensive and complicated issues such as those discussed before, which also apply to the present curriculum of creative and design activities. However, their relevancy and efficiency have been limited by the knowledge of the educator or equipment available in the preschool education centre. Therefore, this education should be both pedagogically and professionally assessed by an academic designer (Thompson, 1995; Schön, 1987). Table 1 illustrates the proposed model derived from these issues.

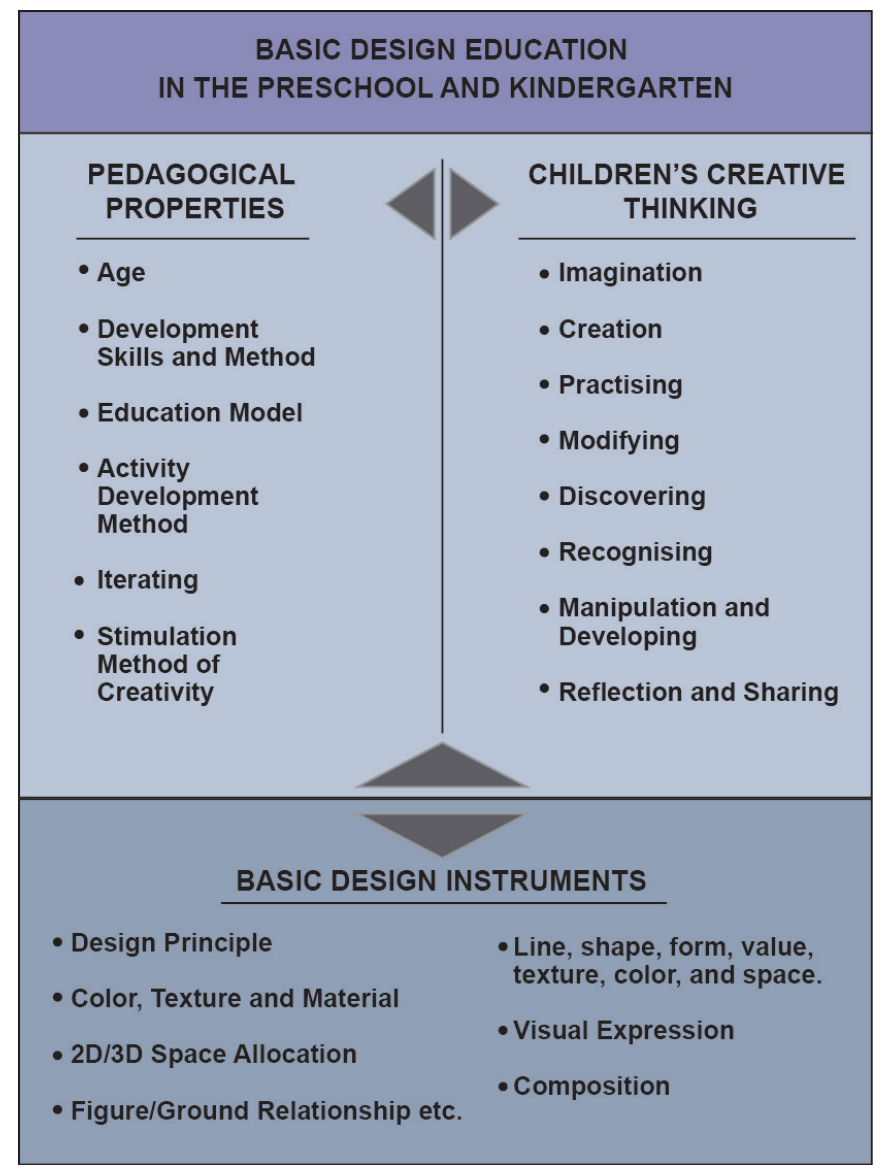

Table 1. Proposal for the "Basic Design Education in Preschool and Kindergarten" Model Note: Pedagogical issues, children's creative thinking skills and basic design instruments are issues that are supposed to be evaluated as a whole 
This model of components in design education in preschool and kindergarten summarises the creative thinking components, pedagogical issues and basic design instruments. The concepts of the creative thinking components are based on the studies of Sawyer (2006), Florida (2002), Brosterman (1997) and Fulghum (1986). The pedagogical issues are based on the studies of Sawyer (2006), Resnick (1998) and Schön (1987). The basic design instruments are based on the studies of Ackermann (2004), Demirbas and Demirkan (2003) and Florida (2002), which cover the dependent and independent variables of the 'Constructing design knowledge within kindergarten education' model: pedagogical issues, children's creative thinking approach and basic design elements. These three variables are described in detail below.

\section{Pedagogical and design issues}

Different socio-philosophical-pedagogical theories on the education models built for and around children led to the construction of our understanding of the current issues and curriculum of basic design during early childhood education. 'It was found that there were statistically significant differences between the performance scores of students having diverse learning styles at various stages of design process' (Demirbas \& Demirkan, 2003, p. 437). The important point here is to provide various learning experiences and methods that emphasize different learning styles during the design process, since each design educator has his/her strategy in communicating with children.

As Schon (1987) proposed, the instructor should refer to all communication means as reflection-in-action. Furthermore, it is important to stimulate the diverging children to bring to the class their range of ideas and creative processes. The sensory, perceptual, motor, linguistic and intellectual abilities of young children have to be indicated in a harmonious and balanced manner while composing design facilities for appropriate age- and skill-related development. Moreover, application and iteration of flexible teaching methods will enhance children's motivation and stimulate their imagination; for example:

- The role of creativity in the learning of children;

- The developmental stages of children's basic design education;

- The philosophy, social context and attitudes of design education at the preschool level; and

- Knowledge of the curriculum (goals, organization, materials, and vocabulary) as it contributes to the growth of children.

\section{Developing the creative thinking skills of children}

There is growing emphasis on creativity, stimulating children's creativity, and improving the talent of preschool children from a very early age; the relations between these branches of design education with other school disciplines for creating an ensemble are important in developing children's personalities in the last years of education (Florida, 2002; Resnick, 1998; Sawyer, 2006).

Thus, children acquire an idea and begin to implement it. They know what equipment and materials they will need and obtain them. An educator is an enabler who offers children any materials that are unavailable but necessary. Such an idea often sparks other new ideas, and the original idea evolves during the process. The participation is seen in children who are excited and involved. The activity draws the attention of other children. All of them are sufficient for the creative process, which consists of imagining, creating, practicing, modifying, discovering, recognising, manipulating, developing, reflecting and sharing. As previously mentioned, these issues have been present in early childhood education and are relevant issues in the design process. However, children need to be stimulated and directed by professionals, 
as well as need to construct the basis for a perceptual, critical and analytic point of view at a very early age, so that they will have the ability to develop it in the future.

\section{Basic design instruments and preschool curriculum}

Basic design principles are fundamental and important as media of instruction for children, such as play, storytelling, puzzles and cartoons, that could be turned into an experience of design (Dudek, 1996). Therefore, the curriculum could provide children with the opportunity to build a model that will guide them in understanding and applying the knowledge, skills, processes and theories of design and in providing a balanced synthesis between the conceptual and physiccal aspects of design:

- To acquire perceptual awareness by identifying and using the elements of design such as line, shape, form, value, texture, colour and space;

- To design concepts based on the elements of design and, in contrast, principles of 2D/3D space organization, e.g. balance, rhythm, emphasis and unity;

- To comprehend cultural heritage through the interaction of design and art in society;

- To utilize the processes and materials appropriate for preschool children;

- To understand self-expression through visual communication of ideas, experiences and feelings;

- To learn the vocabulary peculiar to design issues;

- To use natural and ecological materials allowing healthy growth of children and their awareness of basic design issues from the perspective of order, proportion, principles, etc.;

- To experiment with creative designs, and geometrical and structural forms with colour and texture, and to engage in imaginative and innovative technologies and materials; and

- To design spaces, perspectives and environments whose purpose is to enhance the intuition, imagination and creativity of children along with development of their aesthetic and scientific thoughts (Berthelsen et al., 2009; Demirbas \& Demirkan, 2007; Uluoğlu, 2000).

Children's playful creativity in the preschool period can be regarded as artistic; they are capable of appreciating design and various activities or engaging in them. There can be different kinds of creative activity practices, which will support children's full development and personality during an age in which curiosity for art, design and science is created (Florida, 2002). Correspondingly, children somehow encounter creative activities within their preschool education. Still, they are not professionally structured for design issues. Subsequently, they usually continue to have a traditional type of education, in which creativity is lacking or limited until they start an art or design undergraduate programme. However, students find it difficult to adapt to a very different way of thinking. Therefore, this part of the study attempted to determine whether the design student respondents within the study have had preschool education, the intention of creative activities between preschool and undergraduate academic life and, as a result, the students' performance with regard to basic design issues. Thus, the effects of continuous creative activities from kindergarten to an undergraduate programme on design education were examined.

\section{Conclusion and Recommendations}

The graduates of a design department are expected to be highly motivated, technically competent and mentally prepared to deal with ideas at a professional level (Demirbas \& Demirkan, 
2007). Achieving these outcomes with a four- or five-year education is complicated and discouraging for both student and instructor. This paper emphasises the accumulation of knowledge in design education; as in most other disciplines, the foundation of this knowledge must be founded and built up on during early childhood education. As mentioned above, in some nations, children lack the opportunity to develop their creativity after leaving kindergarten; they begin the traditional type of education, which creates a huge gap between kindergarten and undergraduate design education later on in their life. For this reason, especially in the beginning, students find it difficult to deal with design issues at the undergraduate level in the design departments due to absence or discontinuity of background knowledge, and experience creative issues.

Another offer of the study is a model for the basic construction of design education, which presents and identifies all the relevant independent and dependent variables in terms of pedagogical, creative, basic design issues. In this way, learning and teaching methods aim to balance the creative process with a critical awareness, considering methods and mediums in terms of the developmental aspects of children. Each design outcome tends to be unique, nonrepetitive and immanent in its conception and development. During a design process, each child transforms a field of inquiry into a proposition or scheme. Children have a special point of view, but the learning process could be classified in terms of age and gender.

As a result, design has been integrated into almost all aspects of our lives, either practically or conceptually. The traditional kindergarten approach to learning is ideally suited to the needs of the $21^{\text {st }}$ century (Resnick, 1998). In a society characterized by uncertainty and rapid change, the ability to think creatively is becoming the key to success and satisfaction, both professionally and personally (Florida, 2002). For today's children, nothing is more important than learning to think creatively-learning to come up with innovative solutions to unexpected situations that will continually emerge in their lives (Sawyer, 2006). For this reason, the traditional kindergarten approach has to be professionally reorganised in terms of contemporary design approach, materials and medium of education. The preschool curriculum should cover and comprise both pedagogy and design - multidisciplinary goals, contents and methods of preschool design education - and continue with imparting knowledge and skills in perceiving, planning, implementing, evaluating and developing design skills in their future academic and professional life.

\author{
Meryem Yalcin \\ Assistant Professor \\ TOBB University of Economics and Technology, Ankara, Turkey \\ Department of Interior Architecture and Environmental Design \\ Email address: myalcin@etu.edu.tr
}




\section{References}

Ackermann, E. K. (2004). Constructing knowledge and transforming the world. In M. Tokoro \& L. Steels (Eds.), A learning zone of one's own: Sharing representations and flow in collaborative learning environments (pp. 15-37). Amsterdam: IOS Press

Batič, J. (2014). Implementing change in architectural design in elementary school art education in Slovenia. International Journal of Art and Design Education, 33(1), 130-140. doi: 10.1111/j.14768070.2014.01741.x

Berthelsen, D. C., Brownlee, J. M. \& Johansson, E. (Eds.). (2009). Participatory learning in the early years: Research and pedagogy (pp. 185-202). New York and London: Routledge, Taylor \& Frances Group

Black, A. L. (2001). Grappling with the realities of teaching: Artful representations as sense-making, meaningmaking tools. In Singh, Parlo \& McWilliam, E. (Eds.) Designing Educational Research: Theories, Methods and Practices. Post Pressed, Flaxton, Qld., pp. 59-70

Brosterman, N. (1997). Inventing kindergarten. New York: Harry N. Adams Inc

Bryant, C. K. \& Hungerford, H. R. (1977). An analysis of strategies for teaching environmental concepts and values clarification in kindergarten. The Journal of Environmental Education,9(1), 44-49. doi: 10.1080/00958964.1977.9942015

Chou, H.-W. \& Wang, T. (2000). The influence of learning style and training method on self-efficacy and learning performance in WWW homepage design training. International Journal of Information Management, 20(6), 455-472. doi: 10.1016/S0268-4012(00)00040-2

Demirbas, O. O. \& Demirkan, H. (2003). Focus on architectural design process through learning styles. Design Studies, 24(5), 437-456. doi: 10.1016/S0142-694X(03)00013-9

Demirbas, O. O. \& Demirkan, H. (2007). Learning styles of design students and the relationship of academic performance and gender in design education. Learning and Instruction, 17(3), 345-359. doi: 10.1016/j.learninstruc.2007.02.007

Dudek, M. (1996). Kindergarten architecture: Space for the imagination. London: E. \& F. N. Spon Press, p. 56

Dudek, M. (2000). Kindergarten Architecture: Space for the Imagination. Second edition. London, UK: Spon Press

Ellis, A. \& Morrison, C. (1998). Real age-of-acquisition effects in lexical retrieval. Journal of Experimental Psychology: Learning, Memory \& Cognition, 24, 515-523. doi: 10.1037/0278-7393.24.2.515

Emilson, A. \& Johansson, E. (2009). The desirable toddler in preschool-values communicated in teacher and child interactions. In D. C. Berthelsen, J. M. Brownlee \& E. Johansson (Eds.), Participatory learning in the early years: Research and pedagogy (pp. 61-77). New York and London: Routledge, Taylor \& Frances Group

Fawcett, M. \& Hay, P. (2004). 5x5x5 = creativity in the early years. International Journal of Art and Design Education, 23(3), 234-245. doi: 10.1111/j.1476-8070.2004.00403.x

Florida, R. (2002). The rise of the creative class: And how it's transforming work, leisure, community and everyday life. New York: Basic Books

Fredriksen, B. C. (2011). When past and new experience meet. Negotiating meaning with 3-D materials in the early childhood education. FORMakademisk, 4(1), 65-80. doi: 10.7577/formakademisk.128

Fulghum, R. (1986). All I really need to know I learned in kindergarten: Uncommon thoughts on common things. New York: Ivy Books

Göncu, A., Main, C. \& Abel, B. (2009). Fairness in participation in preschool. In D. Berthelsen, J. Brownlee \& E. Johansson (Eds.), Participatory learning in the early years: Research and pedagogy (pp. 185-202). New York and London: Routledge, Taylor \& Frances Group

Härkönen, U. (2002). Esiopetus ja esiopetussuunnitelma varhaiskasvatuksen viitekehyksessä (Pre-school and pre-school plan for early childhood education framework). Joensuun yliopisto Kasvatustieteiden tiedekunnan selosteita (University of Joensuu bulletins of the Faculty of Education) 84. (99 pp.). Retrieved from http://sokl.uef.fi/harkonen/verkot/esiopetus2002.pdf (in Finnish) 
Hirsh-Pasek, K., Golinkoff, R. M. \& Eyer, D. (2003). Einstein never used flash cards: How our children really learn and why they need to play more and memorize less. Emmaus, PA: Rodale Press

Kolb, D. A. (1984). Experiential learning: Experience as the source of learning and development. Englewood Cliffs, NJ: Prentice Hall

Kolb, A. Y. \& Kolb, D. A. (2005). Learning styles and learning spaces: Enhancing experiential learning in higher education. Academy of Management Learning and Education, 4(2), 193-212. doi: 10.5465/AMLE.2005.17268566

Kvan, T. \& Yunyan J. (2005). Students' learning styles and their correlation with performance in architectural design studio. Design Studies, 26(1), 19-34. doi: 10.1016/j.destud.2004.06.004

Leinonen, L. \& Venninen, T. (2012). Designing learning experiences together with children. Procedia Social and Behavioral Sciences, 45: 466-474. The 5th International Conference of Intercultural Arts Education 2012: Design Learning, University of Helsinki, Finland. doi: 10.1016/j.sbspro.2012.06.583

Lindström, L. (2006). Creativity: What is it? Can you assess it? Can it be taught? International Journal of Art and Design Education, 25(1), 53-66. doi: 10.1111/j.1476-8070.2006.00468.x

Lindström, L. (2011). The multiple faces of visual arts education. International Journal of Art and Design Education, 30(1), 7-17. doi: 10.1111/j.1476-8070.2011.01688.x

Maxwell, S. E. \& Cole, D. A. (1995). Tips for writing (and reading) methodological articles. Psychological Bulletin, 118, 193-198. doi: 10.1037/0033-2909.118.2.193

Niederhauser, D. S., Wetzel, K. \& Lindstrom, D. L. (2004). From manuscript to article: Publishing educational technology research. Contemporary Issues in Technology and Teacher Education, 4(2), 89-136

Oxman, R. E. (1999). Educating the designerly thinker, in W.M. McCracken, C.M. Eastman and W. Newsletter (eds.). Special Issue on Cognition in Design Education, Design Studies 20(2): 105-122

Oxman, R. (2001). "The Mind in Design - A Conceptual Framework for Cognition in Design Education" in C. Eastman, W.M. McCracken and W. Newsletter (Eds.) Knowing and Learning to Design: Cognition in Design Education, pp. 45-47, Elsevier, Oxford

Resnick, M. (1998). Technologies for lifelong kindergarten. Educational Technology Research and Development, 46(4), 43-55. doi: 10.1007/BF02299672

Rosario, J. \& Collazo, E. (1981). Aesthetic codes in context: An exploration in two preschool classrooms. Journal of Aesthetic Education, 15(1), 71-82. doi: 10.2307/3332210

Sawyer, R. K. (2006). Educating for innovation. Thinking Skills and Creativity, 1(1), 41-48. doi: $10.1016 /$ j.tsc.2005.08.001

Schön, D. A. (1987). Educating the reflective practitioner: Toward a new design for teaching and learning in the professions. San Francisco: Jossey-Bass Publishers

Thompson, C. M. (Ed.). (1995). The visual arts and early childhood learning. Reston, VA: The National Art Education Association

Thompson, C. M. (2007). The culture of childhood and the visual arts. In L. Bresler (Ed.), International handbook of research in arts education (pp. 15-28) Dordrecht, Germany: Springer. doi: 10.1007/978-1-4020-3052-9_61

Torracco, R. J. (2005). Writing integrative Literature reviews; Guidelines and examples. Human Resources Development Review, 4, 356-367. doi: 10.1177/1534484305278283

Tomšic`Cerhez, B. (2004). Likovni materiali in tridimenzionalne predstavitve prostora (Art materials and threedimensional presentations of space). Likovna Vzgoja, 5/6, pp.25-37

Uluoğlu, B. (2000). Design knowledge communicated in studio critiques. Design Studies, 21(1), 35-58. doi: 10.1016/S0142-694X(99)00002-2

Vygotsky, L. S. (2004). Imagination and creativity in childhood. Journal of Russian and East European Psychology, 42(1), 7-97. Retrieved from http://masharpe.metapress.com/link.asp?id=265tnearjknc0220 